\title{
Modi looks West? Assessing change and continuity in India's Middle East policy since 2014
}

\author{
Nicolas Blarel ${ }^{1}$ (D)
}

Accepted: 17 May 2021 / Published online: 3 June 2021

(c) The Author(s), under exclusive licence to Springer Nature Limited 2021

\begin{abstract}
Various observers have emphasized a recalibration of India's stance towards the Middle East under Prime Minister Narendra Modi. These accounts have generally highlighted Modi's public overtures toward Israel, including an unprecedented 2017 visit, as public signs of a break with India's traditional pro-Arab and pro-Palestine approach. Others have interpreted Modi's successive visits to the United Arab Emirates, Saudi Arabia, Iran, Qatar, and Oman as indicators of a new outreach to all relevant actors in the region. However, has this diplomatic balancing among regional stakeholders signalled a substantial foreign policy change? Can this apparent policy shift be attributed to the personal preferences of Modi? Or Can India's fluctuating Middle-East policy be explained by a wider number of fluid international and regional opportunities and constraints? Alternatively, can factors such as ideological and religious politics at the national and regional levels also help account for changes (or the absence thereof) in India's Middle-East policy? Building on foreign policy scholarship, this paper offers to derive theoretical understandings and expectations about Modi's role in (re)shaping this regional policy in order to problematizes the conventional understanding of Modi's engagement with the Middle East as a sign of substantial foreign policy change.
\end{abstract}

Keywords India $\cdot$ Middle East $\cdot$ Foreign policy change $\cdot$ Leadership style $\cdot$ Narendra Modi · Israel

The series of visits since 2015 by Indian Prime Minister Narendra Modi to Israel, Saudi Arabia, Iran, United Arab Emirates (UAE), Jordan, Qatar, Oman, Bahrein and the Palestinian territories have highlighted a more active diplomatic engagement from New Delhi towards the broader Middle-East than previous Indian government. Some have interpreted these developments, including an unprecedented visit to Tel Aviv in 2017, as indicators of a shifting Indian approach towards the

Nicolas Blarel

n.r.j.b.blarel@fsw.leidenuniv.nl

1 Leiden University, Leiden, Netherlands 
Middle East, especially with regards to Israel and the Gulf States (Brandenburg and Gopalaswamy 2018; Burton 2019; Pant 2018; Kumaraswamy 2019; Pethiyagoda 2017). Others have argued that there has in fact been more continuity then change in the contours of India's Middle-East policy (Blarel 2019a; Joshi 2015). All observers seem however to agree that the region has always been of strategic importance but that successive Indian governments have opted for different approaches to support Indian interests in this proximate neighbourhood.

It is important to assess Modi's personal role in reshaping India's Middle East policy given that the diplomatic outreach to Israel and especially the Gulf states have been considered by some analysts as one of the Prime Minister's major foreign policy achievements (Tellis 2019). The Modi government has indeed been very vocal about its 'Think West' initiative (which has also been varyingly labelled 'Look West', 'Act West' or 'Link West' over the last five years) that would match the 'Act East' policy and institutionalized engagement of South East Asian economies (Baru 2015; Jaishankar 2015; Mohan 2014). While a tilt to Israel could have been expected, given Modi's expressed preference for a closer political and security relationship with Tel Aviv (Purayil 2020), other drivers such as the quest to secure access to energy resources and investments (Gupta et al. 2019; Hall 2019: 105-106), and the growing engagement with India's diaspora (Hall 2019: 87-88; Pradhan and Mohapatra 2020), have also pushed Modi to prioritize a rapprochement with the Gulf states since 2015 .

This has been an important break with past orthodoxy as states like Saudi Arabia and the UAE had traditionally supported Pakistan because of religious solidarity. Historically, New Delhi had prioritized ties with secular states such as Egypt and Iraq (Mudiam 1994). This paper also identifies a new geopolitical driver behind the rapprochement with the Gulf states which is the perception from the Modi government that this outreach would directly address some of India's domestic security problems. For instance, over the last five years, India has managed to closely cooperate with the Gulf states on issues of transnational terrorism.

Building on the previous Indian governments' initiatives to cautiously engage the Gulf states, Modi's government further exploited changing perceptions within the Arab world of India's economic development and global status (Blarel 2016). Through a series of highly publicized visits and bilateral agreements with Israel, Iran, and Saudi Arabia, Modi also signalled his willingness to break with India's traditional cautious and quiet diplomacy in the region, which had long been considered as necessary to preserve India's diverse economic, energy, and societal interests in the Middle East.

Other scholars (including in this special issue) have argued that Prime Minister Modi's diplomatic initiatives have actually been strongly consistent with past foreign policy practices (Basrur 2017; Ganguly 2017; Gupta et al. 2019; Hall 2019). To contribute to this debate, this paper aims to determine whether the new diplomatic activity under Modi's tenure as Prime Minister has signalled a substantial foreign policy change in India's approach to the Middle East since 2014. The paper also intends to assess whether any potential shift can be directly attributed to the personal preferences and leadership style of Modi or, alternatively, be explained by other international and regional factors. The paper concludes that the public rapprochement with 
Israel since 2014 can be directly traced to Modi's personal preferences, but that the overture to the Gulf states since 2015 can rather be explained by a combination of geopolitical changes in the Middle East and policy entrepreneurship from Modi who exploited these regional developments to push for a new policy agenda towards the region.

In order to support these claims, this paper first briefly looks at the history of India's relations with the Middle East. Second, the paper offers a brief overview of theoretical approaches helping us to determine Modi's role in (re)shaping India's Middle East policy. Third, the paper assesses the degree of continuity and change in India's approach toward the region during Modi's first government from 2014 to 2019. In a fourth section, the paper focuses on the domestic and international political developments in India and the Middle East in 2019-2020 to highlight some of the lingering obstacles which have inhibited Modi's aspiration to push for a fundamental reorientation of India's approach and role in the region. Finally, the paper concludes with a discussion of whether India's approach towards the Middle East can give us some insights into whether the Indian Prime Minister has been willing and/or able to reform India's foreign policy beyond incremental adjustments since his election in 2014.

\section{Historical background: India's Middle East policies (1947-2014)}

In order to be able to determine the nature and extent of any foreign policy change since 2014, it is important to first briefly look at the history of India's engagement of the Middle East and to identify some long-term determinants of India's policies towards the region. Given its geographical location, the Indian subcontinent has been the historical centre of a network of commerce between Middle Eastern and South Asian merchants (Ratnagar 2004; Bose 2006). Cultural and commercial ties were then reinforced by the settlement of Indians in the Gulf and of Arabs on the Western coast of the Indian subcontinent. Starting in the second half of the eighteenth century, the British East India Company built on the pre-existing trading networks and adapted them to its own commercial and strategic needs (Blyth 2003). With the growth in scale of British political control of India, the spread of direct British political and administrative influence on the Middle East also expanded (Darwin 2009; Onley 2007). As a result, the Middle East maintained an important position in political and commercial designs for successive polities in India before and after independence. Independent India's approach to the Middle East has evolved over time due to varying perceptions of its interests in the region, of its material capacities to support these interests, and the local perceptions of India's role in the Middle East. 


\section{Phase 1 (1947-1960s): direct involvement, pragmatism and status-signalling}

Starting from the late 1940s, the newly independent Indian government under Prime Minister Jawaharlal Nehru aimed to distinguish its foreign policy from the imperialist practices of British India. Symbolically, Nehru rejected the Eurocentric terms 'Near East' or 'Middle-East' to adopt a more Asia-centric worldview and began referring to the region as West Asia. ${ }^{1}$ Under Nehru, India also adopted a globalist rhetoric and hoped to provide a leadership role for the larger community of the developing world, notably through the Non-Aligned Movement (NAM). In this context, India viewed the Middle East and other newly decolonized states as partners in this new international movement. India took a strong stance in support of Palestinian and other Arab nationalists in their struggle for liberation against colonial empires. In the early days of the Arab-Israeli conflict, India developed a robust pro-Palestinian stance and did not establish full diplomatic ties with Israel until the 1990s (Blarel 2015).

From its independence in 1947 to the Suez Canal crisis of 1956, India initially pursued a policy of open engagement of all actors in the region, including Egypt, Israel, and Saudi Arabia. India's first prime minister, Jawaharlal Nehru, believed that India should be direct party to the resolution of regional disputes to preserve its influence and interests. As a consequence, India was directly involved in the international negotiations leading to the settlement of crises in Palestine, Lebanon, and Suez in the late 1940s and 1950s (Mudiam 1994). In the 1950s, Nehru and India were perceived as an important extra-regional actor involved in the settlement of regional issues like the Suez crisis and the Lebanon crisis of 1958 (Nayudu 2018). However, India's approach changed after the Suez crisis when it opted for a less interventionist strategy towards the region (Blarel 2015, 124-132). Because of its limited power projection capabilities, India decided to defer to allies, such as Gamal Abdel Nasser's Egypt, to have an influence on regional events. This alignment strategy was also a reaction to the emergence of the U.S.-sponsored Baghdad pact, an alliance system that directly favoured India's rival, Pakistan, and alienated India from other Middle Eastern states such as Iran and Jordan (McGarr 2013, 16-25). Egypt was also instrumental in limiting efforts from Pakistan to isolate India either through Pan-Islamic solidarity or through the Baghdad Pact. During the IndiaPakistan conflict of April 1965, Pakistan was for instance able to mobilize through this alliance network an overwhelming majority of Arab states on its side. Barring Egypt, no Arab state in the Middle East seemed prepared to support India's position. During the conflict, Jordan and Saudi Arabia even gave direct monetary assistance to Pakistan (Blarel 2015: 157-158; Burke 1974: 190). While not directly supportive of India, Nasser's Egypt stayed neutral and helped tone down a pro-Pakistan resolution voted at the Arab Summit of September 1965 in Casablanca (Agwani 1966).

\footnotetext{
1 The West Asian region extends from Turkey to Southern Yemen and From Egypt to Iran. Some scholars also have a broader interpretation of West Asia including Sudan and Afghanistan (Ward 1992: 15).
} 


\section{Phase 2 (1970s-1980s): Constraints and partial disengagement}

In the late 1960s and early 1970s, India's involvement in Middle Eastern affairs was increasingly shaped by economic and energy considerations. The Indian government was concerned about the security of key strategic choke points such as the Straits of Hormuz and the Suez Canal and adjusted India's regional policy in order to preserve its economic and trade interests. In the late 1960s, oil also became a vital necessity to India's growing industrial sector. India's Cairo-centred policy also came under fire when it became clear that diplomatic support for Egypt directly alienated it from Saudi Arabia and Jordan which, in the meantime, furthered its relations with Pakistan. India's pro-Egypt bias also led the Indira Gandhi government to unconditionally support Nasser's military adventurism against Israel in 1967, this despite Egypt's lukewarm support in the 1965 war with Pakistan which escalated to a military confrontation with Israel. India's uncritical pro-Nasser policy led to the alienation of other Arab leaders like King Hussein of Jordan and King Saud of Saudi Arabia who did not agree with Nasser's initiatives. Egypt's military defeat accelerated the decline of Cairo's prominent status in the Pan-Arab world. During the 1971 war between India and Pakistan, most Arab states again sided with Islamabad, notably judging that the Bengali struggle in East Pakistan was an internal Pakistani matter (Blarel 2015: 183-187). Consequently, to attempt to dilute Arab support of Pakistan, but also to meet its growing energy needs, India increasingly developed political links with Iraq and the Gulf States.

Since independence, India's major petroleum suppliers had been Iraq and Saudi Arabia but New Delhi also developed relations in the 1970s with the emerging Gulf states, including the United Arab Emirates (UAE), as well as with Iran to guarantee a steady supply of oil needs for its development. Starting in this period, millions of Indian workers moved to the Gulf states (which needed manpower following the oil boom), and sent back hard currency remittances to India (Jain 2008). The events accompanying October 1973 and the oil crisis then further pushed the Indira Gandhi government to harmonize its Middle Eastern policies with its oil and trade interests, as well as the need to ensure the welfare of the growing diaspora in the region. The oil embargo of 1973 further cemented relations with the Gulf states as New Delhi negotiated bilateral agreements with Iraq, the United Arab Emirates, Qatar and Kuwait, to have guaranteed stable prices over a fixed time period and to ensure a steady flow of oil (Mansingh 1984: 372).

To summarize, India has had historical and material interests in the Middle East. However, because of its limited power projection capabilities following independence, Indian leaders chose to defer to local allies in order to have an influence on regional events. Initially, successive India governments relied on Egypt to indirectly influence regional politics to preserve India's trade and economic interests. However, this policy of alignment with one regional player showed its limits in the late 1960s when the distribution of power and influence in the region moved towards to the oil-rich states. Accordingly, India no longer exclusively deferred to Cairo's judgment on Middle Eastern affairs but realigned itself by developing ties with other regional players like Iraq until the late 1980s. 


\section{Phase 3 (1990s-2000s): structural opportunities and realignment in the post-Cold War era}

A series of structural shocks in the early 1990s encouraged India to reorient its Middle East policy. First, both the Gulf War and the Oslo Peace process revealed important divisions within the Arab world that left India with new diplomatic space to engage with regional actors it had previously neglected due to concerns of diplomatic repercussions (Baral and Mohanty 1992). Second, a domestic economic crisis forced a rethink of India's domestic and foreign economic strategy. Third, India found itself politically isolated as its major political ally and main weapons supplier, the Soviet Union, disintegrated in 1991. Fourth, in the midst of international and domestic flux, the death of Rajiv Gandhi led the Indian National Congress (INC) government to choose a compromise figure, Narasimha Rao, to become India's Prime Minister in 1991. This change in leadership was consequential: with no political constituency or ambitions of his own (he was 70 by the time of his appointment), but with a considerable ministerial and foreign policy experience, Rao was characterized by both cognitive complexity and cognitive openness which made him uniquely able and willing to push for foreign policy adjustments when he came to power (Sitapati 2016, chapter 13).

Taking advantage of this greater political uncertainty at the international and domestic levels, Prime Minister Narasimha Rao reoriented New Delhi's Middle East policy. One major indicator of this policy shift was the establishment of full diplomatic relations, in January 1992, with Israel, a country that Indian political leaders had long neglected for fear of estranging Arab partners or India's own domestic Muslim population (Kumaraswamy 2010). At the regional level, the Kuwait crisis of 1990-1 and its consequences modified Israel's status vis-à-vis Arab states. Internal opposition within the Arab world and widespread criticism regarding the Palestine Liberation Organization's (PLO) support of Iraq during the war limited the negative implications of opening up to Israel. The Iraqi intrusion into Kuwait diverted attention from Israel as the Saddam Hussein regime became the new source of concern in the region (Kumaraswamy 2005). India no longer needed to systematically condemn Israel to obtain Arab sympathies. In addition, a series of Middle Eastern peace initiatives such as the Madrid Conference of October 1991 created a new era in the region where coexistence and negotiations with Israel was possible. These regional consultations created a window of opportunity for India under Rao to develop a strategic partnership with Israel while maintaining relations with other Middle Eastern countries. This new balancing strategy was possible because the Middle East was more of a multipolar region (Iran, Saudi Arabia, Egypt, and Israel). The establishment of diplomatic relations with Israel was also considered by Rao to be a necessary step to improve ties with the U.S., a close Israeli ally, in the post-Cold War era (Blarel 2015: 247-252).

The normalization of ties with Israel not only helped India develop stronger defence and economic relations with Tel Aviv, but also enabled New Delhi to move past old ideological alignments and engage a wider number of Middle Eastern actors, notably to further its energy and economic interests. After 1992, there was a shift in India's foreign policy from a zero-sum approach to the region, or in the 
words of the then Indian Ambassador to Israel Shivshankar Menon an 'either-orsituation', to a policy of multi-engagement of all relevant regional actors (Menon 1997). Indian leaders gradually acknowledged the pragmatism of the Arab leaders themselves. None of these countries wanted to let the Israel-Palestine conflict become an insurmountable obstacle to developing relations with India (Abhyankar 2008: 48-49). In addition, India's economic growth, rising international influence, and new status as a nuclear weapons state in the 1990s gradually made it a major destination for exports, and a venue for investments for most Middle Eastern states (Ansari 2009).

\section{Accounting for change and continuity in Modi's foreign policy}

By looking at the post-independence trajectory India's ties with the Middle East, one can identify diverse and shifting interests driving India's approach to the region such as access to energy resources and especially oil, preserving open trade routes, increasing or maintaining some degree of political influence in the region (notably to counterbalance Pakistan's own diplomatic influence in the Middle East), attracting foreign direct investments, and finally ensuring the welfare of India's growing diaspora in the region since the 1970s. One can argue there has not been any major changes in India's strategic interests in the region since 1947, even if economic, energy, and diaspora considerations only became salient in the 1970s onwards. What evolved over time were in fact the means used to preserve India's interests in the region. For instance, India has moved from a strategy of proactive involvement in regional disputes during the Nehru years (Suez, Lebanon), to aligning with specific privileged partners in the region (Egypt, Iraq), and finally to engaging in omni-balancing all actors and interests in the region (in the 1990s). The choice of these varying strategic and diplomatic strategies has therefore been the result of both evolving geopolitical factors in the Middle-East but also of the ideological and cognitive predispositions of different Indian leaders in power, whether these were Nehru or Rao.

Building on the existing scholarship that emphasizes the role of leadership on foreign policy outcomes, this paper focused on a series of causal mechanisms to assess Modi's role in influencing India's Middle East policy since 2014. First, one part of the scholarship has stressed the importance of exogenous shocks (whether of an international or domestic nature) as key enablers for leaders espousing alternative foreign policy agendas (Blavoukos and Bourantonis 2012; Legro 2005; Mintrom and Luetjens 2017). According to this understanding, foreign policy entrepreneurs are generally political figures with special skills, vision and/or leadership capacity who manage to overcome the inertia of previous foreign policy action to push for a redirection of foreign policy (Hermann 1990; Blavoukos and Bourantonis 2014). For instance, Prime Minister Narasimha Rao can be understood as such a policy entrepreneur who adroitly exploited the international, regional and domestic changes to push for a change in India's approach to the Middle East, and notably a normalization of ties with Israel. This paper therefore tried to determine whether Modi similarly acted as a policy entrepreneur who perceived that opportunity structures in Middle Eastern politics enabled the push for new policy ideas. 
However, where do these new policy ideas come from? A second strand in the leadership and foreign policy scholarship has insisted that leaders' cognitive and/ or ideological predispositions are key intervening variables to account for the timing nature, and degree of policy change (Singer and Hudson 1992; Welch 2005; Ziv 2013). In this context, leadership change, or alteration of personal beliefs, can then lead to alternative foreign policy courses of action. Within this line of argument, some have highlighted the impact of ideational variables such as a leader's ideological beliefs and worldview, when international and institutional conditions are propitious, to explain the process of foreign policy change (Checkel 1997). For instance, one can understand India's attempts to act as a mediator in Middle Eastern disputes and politics in the 1950s as driven by Nehru's own perception of India's key role in global politics (Nayudu 2018). Following this logic, and building on previous work on Modi's ideas and policy beliefs (Basrur 2017; Chacko 2018; Hall 2019; Chatterjee Miller and Sullivan de Estrada 2017), this paper also assessed whether Modi's approach to the Middle East has been shaped by his ideological preferences, notably Hindu nationalism.

\section{Change and continuity under Modi 1.0 (2014-2019)}

\section{Israel: an ideological rapprochement?}

Building on the prediction that ideology matters in understanding Modi's Middle East policy, it is useful to emphasize the role of Hindu nationalism as an ideational force motivating Modi's own worldview, given his membership to the Bharatiya Janata Party (BJP). Some therefore expected a tilt towards Israel during Modi's tenure as Prime Minister given the BJP's consistent aspiration to promote better ties with Israel through their past campaign manifestoes (Jaffrelot 2003; Purayil 2020). The BJP (and its predecessor, the Jana Sangh) had long highlighted that India's long-standing and unconditional backing of the Arab states had never been reciprocated in international institutions when India needed support in its disputes with Pakistan. In a complete break with past policies, the previous BJP government under Prime Minister Atal Bihari Vajpayee (1998-2004) had also welcomed Israeli Prime Minister Ariel Sharon in New Delhi in September 2003. Others have pointed out Modi's favourable disposition towards Israel during his tenure as Chief Minister of the Indian state of Gujarat, when he directly discussed agricultural cooperation with Israel (Blarel 2018). Modi then visited Israel in 2006 and promised that he would come back to Tel Aviv when he became prime minister (Moskowitz 2014). The more pragmatic assumption here could also have been that Modi was personally conscious of the policy benefits of openly cooperating with Israel and that he would assertively push for stronger bilateral relations once in power. Furthermore, by contrast with the previous Vajpayee cabinet that had to govern in the context of a large political coalition, the National Democratic Alliance, the BJP in 2014 had more political and institutional leverage to implement Modi's own policy preferences and to push for a long BJP policy proposal to tilt towards Israel. 
In accordance with both theoretical expectations, Modi attempted to further develop India's ties with Israel. Modi overtly broadcasted existing commercial and defence relationship with Israel. Modi publicly met with Israeli Prime Minister Benjamin Netanyahu on the margins of the UN General Assembly in September 2014 and again during the Paris Climate Change Conference in November 2015. More importantly, Modi became the first sitting Indian Prime Minister to visit Tel Aviv in July 2017 (Kershner and Barry 2017). This visit was soon reciprocated by a Netanyahu visit to New Delhi in January 2018 (Roy 2019). The publicized and increased political interaction since 2014 stood in sharp contrast with the more discreet approach towards Israel adopted by INC-led governments but also by the previous BJP-led government which had been in power from 1998 to 2003. The previous Prime Minister Manmohan Singh had for instance never met with any Israeli ministers during his ten years in office (2004-2014).

In addition, India abstained in July 2015 and in March 2016 from supporting a Palestine-sponsored resolution at the UN Human Rights Council in Geneva to launch a probe by the International Criminal Court against Israel for war crimes during the 2014 Gaza crisis (Mitra 2016). The votes were framed by the Indian media as a "significant move" from India's traditional posture of supporting Pro-Palestine resolutions in UN bodies, a departure from the norm which was also attributed to the stronger personal relationship between Prime Ministers Modi and Netanyahu (Haidar 2015). Breaking with another informal pattern established through previous ministerial visits, Modi also deliberately decided not to make a stop by Ramallah when visiting Israel in 2017 (Stacey and Reed 2017). These diplomatic initiatives led to speculation about a possible shift in India's traditional support of Palestine. In parallel, India and Israel defence ties also expanded under Modi's tenure, as India bought 250 SPICE 2000 bombs from Israel's Rafael systems in 2016, which were then used to strike a supposed terrorist camp in Balakot inside of Pakistan in March 2019 (Rosen 2019), as well as surveillance drones and Spike anti-tank guided missiles in June 2020 in the midst of the boundary dispute with China in Eastern Ladakh (Gupta 2020).

Another hallmark of a shift under Modi has been that, in parallel to the overtures made to Israel, the Indian government also pushed for a reengagement of Iran. The 2015 nuclear deal-the Joint Comprehensive Plan of Action (JCPOA)—signed by Iran and the P5 + 1 was perceived by the Modi government as a window of opportunity to further economic engagement with Iran after years of international embargo (Madan 2018). During his May 2016 visit to Tehran, Modi concluded a tripartite contract (along with Afghanistan) for the expansion of the strategically located Chabahar Port (Iyengar 2016). For an energy-starved and rapidly growing India, the Chabahar Port was perceived as a vital link to the resource- and mineral-rich Central Asian states and Afghanistan. Yet, here again, Modi's foreign policy towards Iran can be viewed as an example of successful political entrepreneurship, capitalizing on efforts initiated by previous Indian governments as the Chabahar deal which had been 13 years in the making. 


\section{Outreach to the Gulf: a bold policy change?}

As highlighted above, a notable policy change that happened under Modi's tenure has been India's strategic rapprochement with the Gulf states. This policy was driven by structural conditions that justified increased public exchanges with the Gulf States. The Gulf states have historically a source of more than $60 \%$ of India's oil and gas requirements and, therefore, critical to its energy security (PTI 2016). The financial value of India's relations with the Gulf countries has also grown over the last decade. While India only represented only 3\% of the Gulf Cooperation Council (GCC)'s total trade in 1992, it represented 11\% in 2012. By 2020, Saudi Arabia and the UAE had become India's fourth- and third-largest trade partners (Pulipaka and Musaddi 2020).

The Modi government has also been wary of increasing Chinese economic and naval involvement in the region. India has been particularly concerned by China's development of ports with dual-use capacities, namely commerce and naval power deployment (Singh 2015). However, India and China have also managed to cooperate given their dependence on the Gulf for energy resources. For instance, India and China have sought to put in place a joint working group to identify possible issues of cooperation in the energy sector, notably mechanisms to mitigate the risks of crude oil price volatility, and to assert their joint weight in discussions with OPEC (the Organization of the Petroleum Exporting Countries) (Choudhary 2019). This was a unique cooperative initiative which followed a decade of competition between the two Asian powers for oil and gas resources in the Middle East.

Energy and ties have traditionally dominated India's relations with the Gulf countries but have also been boosted by the existence of a sizeable Indian diaspora. The Gulf states have been home to approximately 8.9 million Indians who contribute about $\$ 40$ billion in remittances every year and account for about 3 per cent of India's GDP (Shrinivasan 2019). The strong historical transnational ties between this important diaspora and the populations of specific Indian states (Kerala, Andhra Pradesh, Tamil Nadu) also reinforced the need for Indian leadership to see events and ties with Gulf states as directly affecting the welfare of parts of its society.

As a result, the paradigmatic transformation under Modi has been the direct and public acknowledgement of India's important economic trade, diaspora, and also security interests in the Gulf region. Countries like Saudi Arabia have also been willing to promote deepened economic relations and to invest in India. The Saudi King Abdullah visited India in 2006, after a gap of 50 years, and Manmohan Singh was the first Indian Prime Minister to visit Saudi Arabia in 28 years in February 2010. However, the Modi government pushed this burgeoning transactional relationship further and into an economic and political partnership. In an important speech in 2015, India's then Foreign Secretary S. Jaishankar recognised India's "historical presence in the Gulf" but also noted that it had been an "an evolutionary happening that was relatively autonomous of strategic calculations", mostly driven by people and market forces than by "policy" (Jaishankar 2015). Jaishankar suggested then that India, rather than being a passive recipient of outcomes build on the "interdependence" and "combination of human and energy connectivity" to further avenues 
of cooperation and to make India a "credible partner" of regional actors (Jaishankar 2015).

As a result, Modi's multiple and repeated visits to the Gulf countries have been an effort to build on and consolidate existing economic ties. Modi focused his attention on the Gulf with the clear goal of strengthening government-to-government ties by building on existing business-to-business contacts at the highest levels. One specific objective was also to encourage Gulf sovereign wealth funds to invest in Modi's ambitious infrastructure and manufacturing plans at home. Modi therefore chose the UAE as his first destination in August 2015, but also visited Saudi Arabia, Iran and Qatar in 2016, as well as the UAE again in 2018 and 2019. Modi not only travelled again to Saudi Arabia, but also to Oman, and Bahrain in a wide outreach to the Gulf states. Overall, Modi has visited nine Middle Eastern states and territories since 2014, more than his four predecessors combined. The interest has also been reciprocal as Saudi Arabia, the UAE, and other GCC members had increasingly seen India as an important emerging market for their energy exports, foreign investments, and joint venture opportunities. During his 2019 UAE visit, Modi received the Order of Zayed, the UAE's highest civil decoration, in recognition of his role in improving ties between the two countries (Badam 2019). In addition, all of Modi's visits were reciprocated by visits of Gulf dignitaries to New Delhi between 2014 and 2020.

In another break with previous Indian governments, both INC and BJP, Modi also promoted stronger strategic ties with the Gulf states to address national security problems like terrorism. India signed Strategic Partnerships with Saudi Arabia in 2010 (Riyadh Declaration) and with the UAE in 2017. These interactions and agreements have included high-level strategic security dialogues (UAE), inter-state defence cooperation agreements (Qatar, Oman, UAE, Saudi Arabia), intelligence and counter-terrorism cooperation (Saudi Arabia, UAE, Bahrain, Qatar) and convergence in enhancing maritime security in the Indian Ocean region through bilateral activities and in multilateral fora such as the Indian Ocean Rim Association (IORA) and the Indian Ocean Naval Symposium (IONS). While cooperation on counter-terrorism predated Modi's tenure, given that various wanted Indian (and international) terrorist groups, like Dawood Ibrahim, have often transited or resided in the Gulf states, this collaboration was further strengthened and institutionalized since 2015. Discussions during the repeated Modi visits to Abu Dhabi and Riyadh focused specifically on finalizing agreements ensuring the extradition of Pakistani and Indian terrorists as well as limiting money laundering activities from these same groups in the UAE and Saudi Arabia (Government of India 2016; Ministry of External Affairs 2016). The UAE again deported in 2019 a Jaish-e-Mohammed commander, Nisar Ahmed Tantray, who was involved in a 2017 terror attack in Kashmir (Chauhan 2019). Consequently, Modi skilfully exploited an opportunity structure to promote his policy agenda of global counter-terrorism cooperation to improve India's internal security (Siyech 2020).

The new security focus in India-Gulf ties was also explained by geopolitical developments in the Middle East. By refusing to contribute troops to the Saudi-led coalition against the Houthis in Yemen or to quell dissent in Bahrain in 2015, Pakistan sent mixed signals about its unconditional military support for Saudi Arabia 
(Mukashaf 2015). Modi and his government therefore perceived a potential weakening in Pakistan's ties with the Gulf states as an opportunity to reinforce India's own security cooperation with partners in the region.

However, here also, increased counter-terrorism cooperation with the Gulf States has also been a continuation of policies initiated by previous governments instead of a radical policy departure (Siyech 2020). The strategic partnership signed with Saudi Arabia in 2010 included robust anti-terror cooperation measures. Additionally, Saudi Arabia's 2012 deportation of Indian terrorist Sayed Zabiuddin Ansari, who was involved in the 2008 Mumbai terrorist attacks, had already signalled a willingness from Saudi Arabia to cooperate on these issues, even though such coordination had been to the detriment of Pakistan's interests (Lakshmi 2012).

\section{Modi and the Middle East: shedding past inhibitions?}

As a result, it is not just India's capacity to play a different role in the Middle East which has changed over the last decades, but it is also Modi's perception of the importance of the Gulf region which pushed the Indian government to increase public exchanges and to institutionalize pre-existing ad hoc partnerships. Indian leaders previously saw India as an external power to the Middle-East that was on relatively amicable terms with most regional actors and had limited capacities to shape regional outcomes. By contrast, the Modi government recognized the mismatch between growing interests in the Middle East and the limited resources deployed to defend these interests. The Modi government has also been more confident of India's "growing capacities and national branding" which have made it a more "credible partner" to actors in the Middle East (Jaishankar 2015).

Previous governments had also been wary of closely engaging Saudi Arabia and the UAE given historical and privileged ties with Pakistan. The Modi government's diplomatic effort seemed to have been less concerned about Pakistan's traditionally strong influence among the Gulf states. Over the last five years, Saudi Arabia and the UAE have de-hyphenated India and Pakistan and no longer viewed ties with the two South Asian countries as a zero-sum game. While both of Gulf states have preserved their political ties with Pakistan, they have prioritized investments in India. This diplomatic adjustment has had important geopolitical effects, as both Gulf states have toned down their rhetoric condemning India on its policy towards Kashmir, a region disputed between India and Pakistan. For example, India was invited as the guest of honour at the annual Organisation of Islamic Cooperation meeting in Abu Dhabi, UAE, in March 2019, at the peak of the border crisis opposing India and Pakistan. This invitation was both made and maintained in spite of Pakistan's repeated objections to India's participation (Basu 2019). Similarly, the timing of the announcement of Saudi Aramco's \$15 billion investment in India in August 2019, one week after New Delhi's move to revoke Kashmir's special status, seemed like another gesture indicating that Saudi Arabia was no longer willing to let the Kashmir issue be an obstacle to better ties with India (Goel 2019). Finally, in another break with past 
diplomatic practices, the UAE also announced that it viewed India's Kashmir decision of August 2019 as "an internal matter" (Mohan 2019).

Furthermore, whereas discussions over the labour and human rights of Indian expatriate workers had traditionally hounded India's ties with some Gulf states, the Indian diaspora in the Middle East was framed in a new light by both Jaishankar and Modi in a series of statements. In this new rhetoric, the diaspora was presented as an important actor and factor in facilitating better understanding and ties between India and the Gulf. A series of policy initiatives like the eMigrate system in 2015 were also launched by the Indian government to ensure safe migration to the Gulf, to strengthen the outreach initiatives of Indian Gulf embassies, and to opening new grievance redressal windows for expatriate workers (Government of India 2017; Rajan 2017).

\section{Looking ahead: Modi 2.0 and the obstacles to foreign policy change (2019-2020)}

The narrative of a paradigmatic and long-term shift in India's approach to the Middle East has been complicated by a series of event and setbacks since Modi's re-election in May 2019, which have highlighted the remaining structural constraints to a fundamental reorientation of India's foreign policy towards the region. For instance, after initially signalling a pro-Israel tilt, Modi quickly embarked on a course correction and effectively resumed the policy espoused in the past both INC and BJP governments of balanced engagement of Israel and Palestine in multilateral forums. While the Modi government had been more public in its engagement of Israel than previous governments, it has also regularly reasserted its support for the Palestinian Authority. In addition, anticipating domestic criticisms linked to a stand-alone visit to Israel, Modi also invited Palestinian President Mahmood Abbas to New Delhi in May 2017 and reasserted India's traditional position in support for an independent Palestinian nation "at peace with Israel" (Bhattacherjee 2017).

The visit by Modi to Israel also did not prevent India from voting against Israel in December 2017, only a few weeks before Netanyahu's own visit to New Delhi. India also supported a UNGA vote against Donald Trump's unilateral declaration of Jerusalem as Israel's capital, judging that this decision went against international law and previous UN Security Council resolutions (Dutta 2017). Again, in December 2018, India voted against Israel's position by supporting a Resolution for the "achievement, without delay, of a comprehensive, just and lasting peace in the Middle East on the basis of the relevant United Nations resolutions" and which condemned Israel's occupation since 1967 of Arab lands, including East Jerusalem (Blarel 2019b). In November 2020, India equally decided to quadruple its refugee assistance to the UN Reliefs and Works Agency for Palestine Refugees in the Near East (UNRWA) (Nayar 2020). Finally, India's carefully balanced reaction to the Gaza crisis of May 2021, condemning both Hamas and Israel for the escalation of violence, further demonstrate the important continuity in India's effort separate its bilateral ties with Israel from its traditional support of the Palestinian cause in multilateral fora (Nayar 2021). 
As indicated above, the Indian Prime Minister also made his first highly publicized Middle East visit to the UAE in August 2015 and did not travel to Israel until July 2017, only after having visited Saudi Arabia, Iran, and Qatar in the meantime. Instead of an expected alignment with Israel, the tilt towards the Gulf states has demonstrated that Modi's approach to the Middle East was not solely driven by a personal and ideological preference for a privileged partnership with Tel Aviv but also by a pragmatic appraisal of the more immediate strategic interests in the Gulf and of a structural opportunity linked to Pakistan's decreasing influence in that region.

Similarly, many of the defence deals with Israel mentioned in the previous section, such as the purchase of SPICE bombs and of drones, had been negotiated by previous governments and bureaucracies (Blarel 2015; Pant and Sahu 2019). In fact, as argued elsewhere by Blarel and Sarkar, most of the arms trade and joint ventures between the Indian and Israeli defence industries had been driven by the lobbying of India's bureaucracy rather than by the ideological preferences of Modi and the BJP (2019). Consequently, there has in fact been a great deal of consistency in India's Israel policy since 2014.

In addition, India's rapprochement with the Gulf has led to the emergence of old and new challenges which might further constrain the Modi's government leverage in broadening strategic ties with Gulf monarchies. Historically, successive Indian governments had generally favoured quiet diplomacy to not give the impression of aligning too closely with any Middle Eastern partner in order to best protect India's various regional interests, but also by concern of any direct consequences on its domestic politics. Indian policymakers have also been concerned that increasing instability in the Middle East could directly impact the security of its diaspora and indirectly affect sections of its own domestic population which directly receives remittances from the Gulf states, notably in Indian states like Kerala of which the local economy is strongly dependent. India's past inability to influence geopolitics in the Middle East, combined with its lack of a security presence in the region, has previously led to costly evacuations of its diaspora in times of crisis (Xavier 2017).

In addition, the coronavirus pandemic of 2020 has brought up another dilemma for the Modi government which has had to urgently develop contingency plans to support its diaspora in unprecedented health and livelihood challenges, as well as the families and communities which depend on them in Indian states like Kerala, while also not interfering in the domestic and sovereign affairs of Saudi Arabia and the UAE. The Modi government has had to urgently develop a strategy to address the issue of return migration induced by the spread of the virus, the massive layoffs from the lockdowns imposed by the health crisis, and the fall of oil prices. In May 2020, more than 300,000 Indians registered for repatriation from the Gulf, a number which was expected to continue to grow (Laskar 2020). The Modi government has therefore been facing the twin challenges of absorbing large numbers of its returning citizens into a deteriorating job market situation at home, and of coping with an abrupt loss in remittances from the Gulf. In addition, while Prime Minister Modi has mentioned that he had received personal assurances from Gulf leaders that personal attention had been given to the health and safety of Indian nationals, the Indian 
government's power to directly support its migrants in the Gulf states has remained limited despite the diplomatic rapprochement of the last 5 years (Kumar 2020).

Given the important transnational and societal links through its trade and diaspora connections, India has also been worried about interreligious disputes in the Middle East spilling over to its domestic sphere. Disagreements between Western and Indian diplomats at the UN and in other international forums over the Iraq wars of 1991 and 2003, the Lebanon war in 2006, and recently the Syria and Yemen civil wars are therefore the result of varying interpretations of the consequences of certain Middle Eastern crises. Contrary to distant extra- regional powers like the United States, the European Union, or even China, Indian leaders have perceived Middle Eastern conflicts to have direct implications for its own internal security. For instance, India has been directly concerned about the impact that the rise and fall of the Islamic State could have on its own domestic and regional security interests (Syech 2021; Taneja 2019).

For this reason, New Delhi has also been historically critical of Arab states commenting on India's domestic problems such as the Kashmir insurgency (Al-Sulami 2018). However, a shift had become evident as Middle Eastern countries, and especially the Gulf states, had increasingly been more neutral when it came to condemning New Delhi's policies in Indian-administered Kashmir, including a noted silence following the Indian government's decision to strip the state of Jammu and Kashmir of its limited autonomy (Batrawy 2019). The Modi government's active diplomatic outreach to the Gulf states since 2015 and the increasing acknowledgment of India's growing economic profile had until 2020 shielded India from official criticism over the discriminatory nature of India's new citizenship law, as well as mounting reports of anti-Muslim violence following Modi's re-election in May 2019.

However, as India's Muslim community has faced online and physical assaults during the coronavirus crisis, including incidents in which members of the ruling BJP were directly implicated, there were criticisms emerging from the Gulf states with regards to rising Islamophobia in India (Ganguly and Blarel 2020). For example, the Organisation of Islamic Cooperation expressed concerns over reports of maltreatment of Muslims and urged India to take urgent steps to protect the rights of its Muslim minority (Roche 2020). Online hate speech from Indians based in Gulf states have also led to an unprecedented statement from the Indian ambassador to the UAE warning against discrimination (Farooqi 2020). Recognizing the urgency of the matter, India's External Affairs Minister reassured his counterparts in the UAE, Qatar, Oman, and Saudi Arabia and reaffirmed India's commitment to protecting its Muslim minority (Malhotra 2020). While most Gulf states leaders seemed to have publicly welcomed New Delhi's clarifications, it also has become clear that the Modi government's diplomatic gains in the Middle East remain fragile.

Finally, Modi's ambition to maintain strategic ties with Iran following the signing of the JCPOA has also been complicated by the reinstatement of U.S. sanctions against Iran by President Donald Trump in November 2018. Although India's External Affairs Minister initially reacted to the decision by saying that India did not recognize "any country-specific sanctions," the threat of secondary sanctions has dissuaded most Indian firms from developing further ties with Tehran (Verma 2018). Over the last decade, Indian public and private sectors refiners have developed 
alternative supply sources, including Saudi Arabia, the UAE and the U.S. In 2019, India's Ambassador to the U.S. announced that India had effectively ended all imports of oil from Iran as the U.S. ended all exemptions to sanctions against Tehran (Jha 2019).

In another sign of deteriorating ties, in August 2019, Iran's Supreme Leader, Ayatollah Ali Khamenei criticized the Modi government's decision to revoke Kashmir's autonomy in a rare public rebuke of India's policies (Jaffrelot and Rivzi 2020). Finally, four years after the Modi government signed an important agreement to construct a rail line from Chabahar port to Zahedan, along the border with Afghanistan, the Iranian government announced in July 2020 that it would pursue the construction on its own, citing delays from the Indian side in funding the project (Haidar 2020a). Here again, the Modi government's efforts of open engagement of all relevant regional actors was partly reversed due to evolving geopolitical realities in the region.

\section{Conclusion}

Much of the literature on foreign policy change has argued that it is difficult to identify and measure the precise causal influence of particular personalities. As demonstrated in this paper and the rest of this special issue, it has been challenging to distinguish rhetorical innovation from substantial changes in Modi's foreign policy. For instance, Modi's personal preferences have led him to make public overtures to Israel and to suggest the elevation of a transactional partnership to a more political relationship during his tenure, but the change has been more symbolic than substantial, as Modi has mainly resumed or finalized deals negotiated by his predecessors. In addition, India did not discontinue its traditional voting pattern of supporting pro-Palestine resolutions in international fora.

As a result, rather than Modi's beliefs driving change in India's policy towards the Middle-East, this paper has argued that it was rather Modi's role a skilful political entrepreneur, taking advantage of geopolitical developments in the Middle East such as the relative deterioration of ties between Pakistan and Saudi Arabia and the UAE, and the signing of the JCPOA in 2015, as well as a changing perception by Middle Eastern actors of India's status, to push for a renewed Indian engagement with the region. Breaking with the traditional orthodoxy of the Hindu nationalist BJP which has not prioritized the Arab world in its worldview, Modi's outreach to the Gulf states seems to have also been driven by a rational consideration of immediate economic and security benefits. The consolidation of strategic partnerships in the region can be characterized as an example of structural change as long estranged partners like Saudi Arabia and the UAE have now been investing in India's national infrastructure projects and have toned down their traditional criticisms of India's policies in Kashmir.

However, while Modi might have dispensed with traditional Hindu nationalist ideas and ideologies in its foreign policy approach to the Middle East for pragmatic reasons, the Modi government's political agenda, and especially policies that are seen as discriminatory towards the Muslim minority at home, have 
gradually been criticized by the civil society within the Gulf states. It is therefore unclear whether the Modi government's efforts to insulate the bilateral strategic partnerships with the Gulf states from domestic political issues and the welfare of the Indian diaspora in the Gulf states will be sustainable over time. In addition, the Modi government's attempt to maintain a neutral presence in the Middle East by simultaneously engaging Israel, Iran and Saudi Arabia has proved to be increasingly complicated. Whereas India has welcomed and benefited from the recent rapprochement between Israel and the Gulf states (Haidar 2020b), it has gradually distanced itself from Iran. While the Modi government initially had tried to engage Tehran, notably by signing the Chabahar deal in 2016, it quickly became clear over the last five years, that India had gradually tilted towards the Gulf states when looking for energy supply and support in counter-terrorism cooperation. For instance, in striking contrast with the silence of Saudi Arabia and the UAE on the abrogation of Kashmir's autonomous status, Iran overly criticized India's decision.

As a result, the contours of the Modi government's policy towards the Middle East are still in flux and it is not yet clear if the Modi government has succeeded in bringing the transformation it had promised through its 'Think West' policy. It remains to be seen if the tilt towards the Gulf operated over the last five years has constituted a radical and lasting foreign policy shift, analogous to the one initiated by Narasimha Rao in the early 1990s when India normalized ties with Israel. As discussed in the historical overview, it has been a constant challenge for successive Indian governments and leaders to maintain an equidistance between the different poles of the Middle Eastern region. For instance, while the BJP government of Vajpayee in the early 2000 s aimed to elevate ties with Israel, it simultaneously remained prudent in order to preserve ties with other actors in the region.

Increased Chinese involvement and thereby competitive relations in the Middle East between the two Asian powers would also be a new dimension which could (re-)shape India's approach. Until 2020, both New Delhi and Beijing had managed to simultaneously develop strong economic and strategic ties with all relevant actors. Both powers will however have to manage the gradual U.S. disengagement from the region and thereby consider a more proactive political and security involvement, especially to defend their interests and investments. The tilt towards the Gulf states and Israel seems to indicate that the Modi government has begun to slowly adapt to the evolving geopolitical landscape but it is more likely that India will continue to hedge its bets rather than to unequivocally take sides in Middle Eastern disputes.

\section{Declarations}

Conflict of interest The author states that there is no conflict of interest. 


\section{References}

Abhyankar, R.M., ed. 2008. West Asia and the Region: Defining India's Role. New Delhi: Academic Foundation.

Al-Sulami, M. 2018. Organization of Islamic Cooperation Rights Commission Slams Indian Violations in Kashmir. Arab News, 7 May. www.arabnews.com/node/1298326/world?page=112. Accessed 15 July 2020.

Ansari, H. 2009. India and the Gulf. In India and the Gulf, ed. I.P. Khosla. New Delhi: Konark Publications.

Badam, R.T. 2019. Indian PM Narendra Modi's visit to UAE shows strength of friendship between two countries. The National, 23 August. https:/www.thenational.ae/uae/government/indian-pm-naren dra-modi-s-visit-to-uae-shows-strength-of-friendship-between-two-countries-1.900289. Accessed 15 July 2020.

Baral, J.K., and J.N. Mohanty. 1992. India and the Gulf Crisis: The Response of a Minority Government. Pacific Affairs 65 (3): 368-384.

Baru, S. 2015. The sprouting of the 'Look West' policy. The Hindu, 19 August. https://www.thehindu. com/opinion/lead/sanjaya-baru-writes-the-sprouting-of-the-look-west-policy/article7554403.ece. Accessed 15 July 2020.

Basrur, R. 2017. Modi's Foreign Policy Fundamentals: A Trajectory Unchanged. International Affairs 93 (1): 7-26.

Basu, Nayanima. 2019. OIC invite to India as 'guest of honour' comes 50 years after major snub at launch. The Print, 24 February. https://theprint.in/diplomacy/oic-invite-to-india-as-guest-of-honour-comes-50-years-after-major-snub-at-launch/197255/. Accessed 15 July 2020.

Batrawy, A. 2019. Indian Business Ties Underpin Muted Arab Response to Kashmir. Associated Press News Middle East, 16 August. https://apnews.com/50c0012ce1c445db955a09b86732ce69. Accessed 15 July 2020.

Bhattacherjee. 2017. Abbas visit signals a shift. The Hindu, 14 May. http://www.thehindu.com/news/natio nal/abbas-visit-signals-a-shift/article18452142.ece. Accessed 14 Jan 2018.

Blarel, N. 2015. The Evolution of India's Israel Policy: Continuity, Change, and Compromise Since 1922. New Delhi: Oxford University Press.

Blarel, N. 2016. Recalibrating India's Middle East Policy. Carnegie Endowment of International Peace paper, 15 April. https://carnegieindia.org/2016/04/15/recalibrating-india-s-middle-east-policypub-63344. Accessed 15 July 2020.

Blarel, N. 2018. Modi, Pawar and Deve Gowda as CMs led India-Israel ties. Indian Express. 17 January. https://indianexpress.com/article/opinion/benjamin-netanyahu-narendra-modi-sharad-pawar-devegowda-india-israel-5028028/. Accessed 15 July 2020.

Blarel, N. 2019a. Looking West? Evaluating Change and Continuity in Modi's Middle East Policy. International Studies Perspectives 20 (1): 25-29.

Blarel, N. 2019b. Contextualising India's Highly Publicised June 6 Vote on Israel-Palestine in the UN. The Wire, 14 June. https://thewire.in/diplomacy/india-highly-publicised-june-6-vote-israel-pales tine-un. Accessed 15 July 2020.

Blarel, N., and J. Sarkar. 2019. Substate Organizations as Foreign Policy Agents: New Evidence and Theory from India, Israel, and France. Foreign Policy Analysis 15 (3): 413-431.

Blavoukos, S., and D. Bourantonis. 2012. Policy Entrepreneurs and Foreign Policy Change: The GreekTurkish Rapprochement in the 1990s. Government and Opposition 47 (4): 597-617.

Blavoukos, S., and D. Bourantonis. 2014. Identifying parameters of foreign policy change: An eclectic approach. Cooperation and Conflict 49 (4): 483-500.

Blyth, R. 2003. The Empire of the Raj. India, Eastern Africa and the Middle East 1858-1947. New York: Palgrave.

Bose, S. 2006. A Hundred Horizons: The Indian Ocean in the Age of Global Empire. Cambridge, MA: Harvard University Press.

Brandenburg, R., and B. Gopalaswamy. 2018. India's Growing Role in the Middle East. The Diplomat, 3 April. https://thediplomat.com/2018/04/indias-growing-role-in-the-middle-east/. Accessed 15 July 2020.

Burke, S.M. 1974. Mainsprings of Indian and Pakistani Foreign Policies. Minneapolis: University of Minnesota Press. 
Burton, G. 2019. India's "Look West” Policy in the Middle East under Modi. Middle East Institute Policy Analysis, 6 August. https://www.mei.edu/publications/indias-look-west-policy-middle-east-undermodi. Accessed 15 July 2020.

Chacko, P. 2018. The Right turn in India: Authoritarianism, Populism and Neoliberalisation. Journal of Contemporary Asia 48 (4): 541-565.

Chatterjee Miller, M., and K. Sullivan de Estrada. 2017. Pragmatism in Indian Foreign Policy: How Ideas Constrain Modi. International Affairs 93 (1): 27-49.

Chauhan, N. 2019. UAE deports Jaish terrorist Nisar Tantray wanted for 2017 CRPF camp attack in Kashmir: NIA. Hindustan Times, 3 April. https://www.hindustantimes.com/india-news/nisar-tantr ay-jem-terrorist-wanted-for-2017-lethpora-attack-arrested-by-nia/story-Ti4oJbrDuZTmK1Tg9aDK 9L.html. Accessed 15 July 2020.

Chechel, J. 1997. Ideas and International Political Change: Soviet/Russian Behavior and the End of the Cold War. New Haven, CT: Yale University Press.

Choudhary. 2019. India, China Set Up Joint Working Group to Tackle Crude Volatility. The Economic Times, 1 May. https://economictimes.indiatimes.com/industry/energy/oil-gas/india-china-set-upjoint-working-group-to-tackle-crude-volatility/articleshow/69120462.cms. Accessed 15 Nov 2020.

Darwin, J. 2009. The Empire Project: The Rise and Fall of the British World-System, 1830-1970. Cambridge: Cambridge University Press.

Dutta, P.K. 2017. Why India voted against US, Israel on Jerusalem at United Nations. India Today, 22 December. https://www.indiatoday.in/world/story/why-india-voted-against-us-israel-on-jerusalemat-united-nations-1114436-2017-12-22. Accessed 15 July 2020.

Farooqi, M. 2020. India and UAE share value of non-discrimination, says ambassador. Gulf News, 20 April. https://gulfnews.com/uae/india-and-uae-share-value-of-non-discrimination-says-ambas sador-1.71075552. Accessed 15 July 2020.

Ganguly, S. 2017. Has Modi Truly Changed India's Foreign Policy? The Washington Quarterly 40 (2): 131-143.

Ganguly, S., and N. Blarel. 2020. Why Gulf States Are Backtracking on India. Foreign Policy, 5 May. https://foreignpolicy.com/2020/05/05/gulf-states-backtracking-india/. Accessed 15 July 2020.

Goel, V. 2019. As Saudis and Indians Grow Closer, a \$15 Billion Deal Blooms. New York Times, 12 August. https://www.nytimes.com/2019/08/12/business/reliance-india-saudi-aramco-oil.html. Accessed 15 July 2020.

Government of India. 2016. India-Saudi Arabia Joint Statement During the Visit of Prime Minister to Saudi Arabia. http://pib.nic.in/newsite/PrintRelease.aspx?relid=138531. Accessed 2 July 2016.

Government of India, 2017. Ministry of External Affairs, Welfare and Protection of Indians Abroad: Handbook of Indian Centre for Migration. New Delhi. https://mea.gov.in/images/Revised_ICM_ Booklet_17032017.pdf. Accessed 15 July 2020.

Gupta, S. 2020. India increases tech surveillance on Ladakh LAC with Israeli Heron drones. Hindustan Times, 23 June. https://www.hindustantimes.com/india-news/surveillance-shored-up-forces-addedin-ladakh/story-e1GBA1qGwodVr1lm2L4LMJ.html. Accessed 15 July 2020.

Gupta, S., R.D. Mullen, R. Basrur, I. Hall, N. Blarel, M.S. Pardesi, and S. Ganguly. 2019. Indian Foreign Policy under Modi: A New Brand or Just Repackaging? International Studies Perspectives 20 (1): $1-45$.

Haidar, S. 2015. India abstains from UNHRC vote against Israel. The Hindu, 3 July. https://www.thehi ndu.com/news/india-abstains-from-unhrc-vote-against-israel/article7383796.ece. Accessed 15 July 2020.

Haidar, S. 2020a. Iran drops India from Chabahar rail project, cites funding delay. The Hindu, 14 July. https://www.thehindu.com/news/national/iran-drops-india-from-chabahar-rail-project-cites-fundi ng-delay/article32072428.ece?homepage=true\&utm_campaign=socialflow. Accessed 15 July 2020.

Haidar, S. 2020b. India Welcomes UAE-Israel Agreement. The Hindu, 14 August. https://www.thehindu. com/news/national/india-welcomes-uae-israel-agreement/article32358126.ece. Accessed 25 Feb 2021.

Hall, I. 2019. Modi and the Reinvention of Indian Foreign Policy. Bristol: Bristol University Press.

Hermann, C.F. 1990. Changing Course: When Governments Choose to Redirect Foreign Policy. International Studies Quarterly 34 (1): 3-21.

Iyengar, R. 2016. What Indian Prime Minister Narendra Modi’s Visit to Iran Means for Asia. Time, 24 May. http://time.com/4346033/modi-rouhani-india-iran-chabahar-agreement-afghanistan-china/. Accessed 13 July 2018. 
Jaffrelot, C. 2003. Inde-Israel: Le Nouvel Element-Cle de l'Axe du Bien? Critique Internationale 21 (4): 24-32.

Jaffrelot, C., and H.A. Rivzi. 2020. Muslim Countries with Which India Had Increasingly Good Relations Have Become Less Friendly. Indian Express, 22 April. https://indianexpress.com/article/opinion/ strap-muslim-countries-with-which-india-had-increasingly-good-relations-have-become-less-frien dly-6373721/. Accessed 15 July 2020.

Jain, P. 2008. Indian Diaspora in West Asia. In West Asia and the Region: Defining India's Role, ed. R.M. Abhyankar. New Delhi: Academic Foundation.

Jaishankar, S. 2015. Speech by Foreign Secretary at Raisina Dialogue in New Delhi. Ministry of External A airs, Government of India, 2 March. https://mea.gov.in/Speeches-Statements.htm?dtl/26433/ Speech_by_Foreign_Secretary_at_Raisina_Dialogue_in_New_Delhi_March_2_2015. Accessed 15 July 2020.

Jha, L.K. 2019. US Rules Out Sanction Exemptions to Countries from Iranian Oil Import. The Wire, 29 May. https://thewire.in/world/us-rules-out-sanction-exemptions-to-countries-from-iranian-oilimport. Accessed 15 July 2020.

Joshi, S. 2015. India and the Middle-East. Asian Affairs 46 (2): 251-269.

Kershner, I., and E. Barry. 2017. Indian Premier, in Israel Visit, Seeks to Break Barriers in Trade and History. New York Times, July 4. https://www.nytimes.com/2017/07/04/world/middleeast/india-israelnarendra-modi-benjamin-netanyahu.html. Accessed 15 July 2020.

Kumar, S. 2020. India Cannot Forget its Migrant Workers Stranded in the Gulf. The Wire, 1 April. https://thewire.in/labour/coronavirus-india-cannot-forget-its-migrant-workers-stranded-in-the-gulf. Accessed 15 July 2020.

Kumaraswamy, P.R. 2005. Israel's New Arch of Friendship: India, Russia and Turkey. Dubai: Gulf Research Center Research Papers.

Kumaraswamy, P.R. 2010. India's Israel Policy. New York: Columbia University Press.

Kumaraswamy, P.R. 2019. Modi transforms India's approach to the Middle East. East Asia Forum, 11 October. https://www.eastasiaforum.org/2019/10/11/modi-transforms-indias-approach-to-the-middle-east/. Accessed 15 July 2020.

Lakshmi, R. 2012. Saudi Arabia's Policy Shift Toward India Helps Nab Terror Suspects. Washington Post, 6 July. https://www.washingtonpost.com/world/asia_pacific/saudi-arabias-policy-shift-toward-indiahelps-nab-terror-suspects/2012/07/gJQAlOXtRW_story.html?noredirect=on\&utm_term=.9c3bdf6a2c bd. Accessed 13 July 2018.

Laskar, R.H. 2020. Over 300,000 Indians register to return from Gulf region, only those with 'compelling reasons' to be brought back in first phase. Hindustan Times, 5 May. https://www.hindustantimes.com/ india-news/over-300-000-indians-register-to-return-from-gulf-region-only-those-with-compellingreasons-to-be-brought-back-in-first-phase/story-A4qNuaOzlJVQnIclILXxgO.html. Accessed 15 July 2020.

Legro, J.W. 2005. Rethinking the World: Great Power Strategies and International Order. Ithaca: Cornell University Press.

Madan, T. 2018. What Trump's JCPOA withdrawal means for India. Brookings: Order from Chaos series, 9 May. https://www.brookings.edu/blog/order-from-chaos/2018/05/09/what-trumps-jcpoa-withdrawalmeans-for-india/. Accessed 15 July 2020.

Malhotra, Jyoti. 2020. As Gulf calls for an 'India without Islamophobia,' Jaishankar works the phones. The Print, 28 April. https://theprint.in/opinion/global-print/gulf-calls-india-without-islamophobia-jaish ankar-works-phones/410159/. Accessed 15 July 2020.

Mansingh, S. 1984. India's Search for Power: Indira Gandhi's Foreign Policy 1966-1982. New Delhi: Sage Publications.

McGarr, P.M. 2013. The Cold War in South Asia: Britain, the United States and the Indian Subcontinent, 1945-1965. Cambridge: Cambridge University Press.

Menon, Shivshankar. 1997. Indian Foreign Policy in the Middle-East. Palestinian Academic Society for the Study of International Affairs, 7 May. http://www.passia.org/meetings/97/meet04.htm. Accessed 9 Mar 2013.

Ministry of External Affairs. 2016. India-UAE Joint Statement During the State Visit of Crown Prince of Abu Dhabi. Government of India. Abu Dhabi, 12 February. https://www.mea.gov.in/bilateral-docum ents.htm?dt1/26349/India7UAE7Joint7Statement7during7the7State7Visit7of7Crown7Prince7of7Ab u7Dhabi Accessed 2 July 2016.

Mintrom, M., and J. Luetjens. 2017. Policy Entrepreneurs and Foreign Policy Decision Making. Oxford Research Encyclopedia, Politics. https://doi.org/10.1093/acrefore/9780190228637.013.463. https:// 
oxfordre.com/politics/view/10.1093/acrefore/9780190228637.001.0001/acrefore-9780190228637-e463. Accessed 15 July 2020.

Mitra, D. 2016. India Votes Against Israel on Key Settlements Resolution, but Abstains Again on War Crimes. The Wire, 26 March. https://thewire.in/diplomacy/india-votes-against-israel-on-key-settl ements-resolution-but-abstains-again-on-war-crimes. Accessed 15 July 2020.

Mohan, C.R. 2014. Modi and the Middle East: Towards a Link West Policy. Indian Express, 5 October. https://indianexpress.com/article/opinion/columns/modi-and-the-middle-east-towards-a-link-west-policy/. Accessed 15 July 2020.

Mohan, G. 2019. UAE backs India on Article 370, says Kashmir its internal matter. India Today, 6 August. https://www.indiatoday.in/india/story/article-370-jammu-kashmir-uae-ambassador-dr-al-banna-15779 18-2019-08-06. Accessed 15 July 2020.

Moskowitz, J. 2014. Is Narendra Modi, India's New Prime Minister, Israel's New Best Friend? Tablet. May 23. https://www.tabletmag.com/jewish-news-and-politics/173767/modi-israels-new-best-friend. Accessed 15 July 2020.

Mudiam, P.R. 1994. India and the Middle East. London: British Academic Press.

Mukashaf, M. 2015. Pakistan declines Saudi call for armed support in Yemen fight. Reuters. April 10. https:// www.reuters.com/article/us-yemen-security-idUSKBNON10LO20150410. Accessed 24 Feb 2021.

Nayar, K.P. 2020. Modi govt's atypical policy on Palestine. The Tribune, 23 November. https://www.tribu neindia.com/news/comment/modi-govts-atypical-policy-on-palestine-174515. Accessed 24 Nov 2021.

Nayar, K.P. 2021. India Walks a Tightrope on Gaza Conflict. The Tribune, 24 May. https://www.tribu neindia.com/news/comment/india-walks-a-tightrope-on-gaza-conflict-257508. Accessed 26 May 2021.

Nayudu, S.K. 2018. 'In the Very Eye of the Storm': India, the UN, and the Lebanon Crisis of 1958. Cold War History 18 (2): 221-237.

Onley, J. 2007. The Arabian Frontier of the British Raj: Merchants, Rulers and British in the NineteenthCentury Gulf. Oxford: Oxford University Press.

Pant, H. 2018. India's Nuanced Middle East Policy. The Diplomat, 15 December. https://thediplomat.com/ 2018/12/indias-nuanced-middle-east-policy/. Accessed 15 July 2020.

Pant, H.V., and A. Sahu. 2019. Israel's Arms Sales to India: Bedrock of a Strategic Partnership. Observer Research Foundation Issue Brief 311, September. https://www.orfonline.org/research/israels-armssales-to-india-bedrock-of-a-strategic-partnership-55101/\#_ednref8. Accessed 15 July 2020.

Pethiyagoda, K. 2017. India's shifting role in Middle East affairs. The National, 24 April. Accessed 15 July 2020.

Pradhan, R., and A. Mohapatra. 2020. India's Diaspora Policy: Evidence of Soft Power Diplomacy Under Modi. South Asian Diaspora. https://doi.org/10.1080/19438192.2020.1712792.

Press Trust of India (PTI). 2016. India's oil import from Middle East rises to 59\%. Livemint, 25 April 25. https://www.livemint.com/Industry/9n0jzqdP24PmBB13sjRYQJ/Indias-oil-import-from-Middle-Eastrises-to-59.html. Accessed 15 July 2020.

Pulipaka, S., and M. Musaddi. 2020. Power shifts and re-calibrations: India and the Gulf. The Economic Times, 14 February. https://economictimes.indiatimes.com/blogs/et-commentary/power-shifts-and-recalibrations-india-and-the-gulf/. Accessed 15 July 2020.

Purayil, M.P. 2020. Shifting trajectory in India-Israel relations under Modi. Israel Affairs 26 (3): 471-483.

Rajan, S.I., ed. 2017. India Migration Reader. New York: Routledge.

Ratnagar, S. 2004. Trading Encounters: From the Euphrates to the Indus in the Bronze Age. New York: Oxford University Press.

Roche, Elizabeth. 2020. India slams OIC's remarks over reports of maltreatment of Muslims. Livemint, 23 April. https://www.livemint.com/news/india/india-slams-oic-s-remarks-over-reports-of-maltreatmentof-muslims-11587656010581.html.

Rosen, A. 2019. As Its Conflict with Pakistan Heats Up, India Looks to Israel for Arms, Tactics. Tablet, 8 March. https://www.tabletmag.com/sections/news/articles/india-looks-to-israel-for-arms. Accessed 15 July 2020.

Roy, P. 2019. Benjamin Netanyahu's State Visit to India. Israel Affairs 25 (5): 788-802.

Shrinivasan, R. 2019. India was the top recipient of remittances worldwide in 2018. The Eonomic Times, 20 July. https://economictimes.indiatimes.com/nri/forex-and-remittance/india-was-the-top-recipientof-remittances-worldwide-in-2018/articleshow/70310386.cms?utm_source=contentofinterest\&utm_ medium=text\&utm_campaign=cppst. Accessed 15 July 2020.

Singer, E., and V.M. Hudson. 1992. Political Psychology and Foreign Policy. Boulder: Westview Press. 
Singh, A. 2015. China's 'Maritime Bases' in the IOR: A Chronicle of Dominance Foretold. Strategic Analysis 39 (3): 296-297.

Sitapati, V. 2016. Half-Lion: How P.V Narasimha Rao Transformed India. New Delhi: Penguin Books India.

Siyech, M.S. 2020. Understanding India's Increased Counter Terrorism Relations with Saudi Arabia and the UAE. India Review 19 (4): 351-375.

Stacey, K., and J. Reed. 2017. Modi Visit Marks Deepening Relations Between India and Israel. Financial Times, July 3. https://www.ft.com/content/2e86e43a-5bf1-11e7-9bc8-8055f264aa8b. Accessed 15 July 2020.

Syech, M.S. 2021. India's Foreign Fighter Puzzle. South Asia: Journal of South Asian Studies. https://doi.org/ 10.1080/00856401.2021.1864706.

Taneja, K. 2019. The ISIS Peril: The World's Most Feared Terror Group and Its Shadow on South Asia. New Delhi: Penguin Random House India.

Tellis, A. 2019. The three codes Modi cracked to give India a huge foreign policy jumpstart. The Economic Times, 24 March. https://economictimes.indiatimes.com/news/politics-and-nation/how-modi-changedindias-strategic-fortunes/articleshow/68539699.cms?utm_source=contentofinterest\&utm_medium= text\&utm_campaign=cppst. Accessed 15 July 2020.

Verma, N. 2018. India says it only follows U.N. sanctions, not U.S. sanctions on Iran. Reuters, 28 May. https://www.reuters.com/article/us-india-iran/india-says-it-only-follows-u-n-sanctions-not-u-s-sanct ions-on-iran-idUSKCN1IT0WJ. Accessed 15 July 2020.

Ward, R. 1992. India's Pro-Arab Policy: A Study in Continuity. New York: Praeger.

Welch, D. 2005. Painful Choices: A Theory of Foreign Policy Change. Princeton: Princeton University Press.

Xavier, C. 2017. India's Expatriate Evacuation Operations: Brining the Diaspora Home. Carnegie Endowment for International Peace Paper, 4 January. https://carneg-ieindia.org/2017/01/04/india-s-expat riate-evacuation-operations-bringing-diaspora-home-pub-66573. Accessed 15 July 2020.

Ziv, G. 2013. Simple vs. Complex Learning Revisited: Israeli Prime Ministers and the Question of a Palestinian State. Foreign Policy Analysis 9 (2): 203-222.

Publisher's Note Springer Nature remains neutral with regard to jurisdictional claims in published maps and institutional affiliations. 